\title{
DEVELOPMENT OF THE ADMINISTRATIVE LAW IN GEORGIA
}

Purpose. In 1999 the adoption of the General Administrative Code and Administrative Procedure Code in Georgia gave basis for creation of the new administrative law, since before the entry into force of the above-mentioned codes, Georgia had no tradition of the administrative law and, hence, no practice of the administrative justice. In Georgia being part of the Soviet Union, and in the Soviet Union overall, the administrative law did not exist with the understanding that is regulated by the modern administrative law. The communist doctrine of the administrative law radically differs from the modern administrative law because in those times the administrative legislation was mainly defining the citizens' obligations before the administration, rather than ensuring citizens' rights and protection of their interests.

Methods. Therefore, the article discusses development stages of the administrative law, the path gone through by the administrative law starting from the formulation until present time, also the Soviet heritage and its influence on the development of the administrative law is discussed, along with the influence of the European reception and establishment within the Georgian legislation, the core factors are analyzed, which caused the necessity of the creation of new administrative law.

Results. The significant part in the article is devoted to the discussion of the subject of administrative law and system of administrative law on the example of the Georgian administrative law. The core elements of the implementation of public administration are discussed, the notion of the administrative body, forms of activity of the administrative body and basic principles that are characteristic to the Georgian administrative law.

Conclusions. In this regard, the important place is given to particularities of the administrative proceeding and judicial process in Georgia, namely, so called "prejudicial" rule of appealing within the administrative body, suspensive effect of the administrative appeal, principles of disposition and inquisition in the administrative process, as well as the institute of the amicus curiae is discussed, as a particularity of the Georgian administrative justice.

Key words: Georgian administrative law, reception of the legal system, General Administrative Code of Georgia, Administrative Procedure Code of Georgia. 


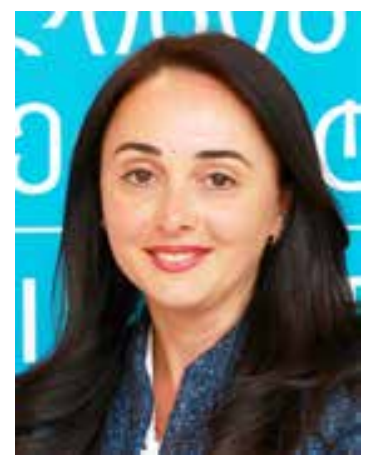

Ketevan Tskhadadze, Dean of the Law Faculty of the Open University Tbilisi,

Doctor of Law, Professor orcid.org/0000-0003-0585-6943 k.tskhadadze@openuni.edu.ge

\section{Introduction}

The purpose of the modern administrative law is to protect persons from the bureaucratic arbitrariness of the administrative body, at the same time, make the legal-administrative relations emerged between them more flexible and effective. As far as the administrative law relates to everyday life, the factual and, at the same time, legal diversity of the modern world brings on the agenda the modernization of public administration and its regulation on legislative level.

In Georgia, the adoption of General Administrative Code and the Administrative Procedure Code in 1999 played significant role in the reformation of the administrative law. The adoption of these codes created the foundation for the administrative law as a discipline, since the administrative law did not exist as an independent discipline. The General Administrative Code stipulated the notion of administrative body, the general provisions and principles of activity of the administrative body for the first time. Besides, the rules for the decision-making in the process of execution of public administration, deliberation with regard to the administrative appeals and grounds for state responsibility were defined. Whereas the adoption of the Administrative Procedure Code, has initiated the execution of administrative justice. This Code prescribed the basic principles of the process, procedural legal capacity, rules of jurisdiction in administrative courts, rules for delivering judgments and filing appeals.

Amendments in the mentioned codes were introduced gradually, which clarified and completed those provisions that had some gaps as emerged by the practice. Consequently, the reformation of the administrative law is ongoing nowadays as well. Representatives of academics, practitioners and international experts are involved in the mentioned process. Their work facilitates systemic and disciplinary study of the administrative law, as well as development of administrative law in Georgia.

The purpose of the presented article is to make a certain contribution to the development of the administrative discipline, to the complex study of issues related to administrative law, which is possible by consideration, analysis and delivering particular conclusions on the issues linked with the creation of the administrative law as an independent subject, on one hand, and, on the other hand, on issues related to its functioning.

The article discusses stages of development of the administrative law, the path it has gone through from the establishment up to now, the main aspects of the soviet heritage 
in the administrative law, the influence of European reception and incorporation into the Georgian legislation, those important factors, which caused the necessity of the creation of administrative law. The core provisions will be analyzed, which are characteristic to the administrative proceeding and judicial process.

\section{Stages of the development of administrative law in Georgia}

\subsection{European reception in the Georgian legislation}

It shall be noted, that Georgian law never has been the country closed and hidden into its national values. It always showed big interest towards progressive culture and in this way improved its own culture. Moreover, considering the geopolitical location of Georgia, it always has been influenced by the east-west culture (Zoidze, 2005: 20). Georgian law always was remarkable for the exceptional scope of borrowing foreign law (Korkunov, 2004: 281). However, it shall not be understood as striving towards reception of Georgia was done or is done by the direct transposition of foreign law. Georgian legislator always tries to have harmonized and synthesized law. Herein, we shall note that continuous strive and development of Georgia was interrupted by Russian annexation and it had no possibility to implement serious reforms in the area of law during 70 years ${ }^{1}$. Hence, the first stage of development of the Georgian administrative law starts only after dismantlement of the Soviet Union and declaration of the independence of Georgia ${ }^{2}$.

At this point, it shall be noted that Europeanisation of the Georgian administrative law was not a goal in itself, but such obligation derives from the constitution itself. As far as the constitutional law defines the main principles and provisions of any area of law. According to the opinions expressed in literature, we can find the dominant regulation of the constitutional law mostly in the administrative law. In general the core principles of constitutional law in the administrative law, comparing to all other areas, may be said that are directed with more intensity. In particular, by virtue of administrative legislation the content and principles of the constitutional law are specified (Tskhadadze, 2016: 5).

\subsection{The heritage of the Soviet Union in administrative law}

Because of the communist regime existing in Georgia, the administrative law developed in different direction. According to the communist doctrine, administrative bodies are instruments for only expressing and implementing the will of a State (Adeishvili, Samkharauli, 2003: 3). In general, the concept existing in those times did not arouse the necessity of having mechanisms for protecting citizens' rights in relation to administrative bodies and it was based on the restrictive rules in the administrative legal relationships, as well as types of responsibilities for the breach of these rules. All these

\footnotetext{
${ }^{1}$ On February 24 of 1921, Soviet Russian troops entered Georgia and took the whole territory.

${ }^{2}$ On 31 March of 1991 referendum was conducted in Georgia in which 90,3\% of the whole population participated. On the question of referendum - whether they want to restore the independence on the basis of the declaration of independent act of 26 May of 1918, the $98,9 \%$ of the referendum participants answered positively. Based on this, on 9 April of 1991 the act on the restoration of the Independence of Georgia was adopted. Restoration of independence based on the independence act of 26 May of 1918 meant that after restoration of independence the State of Georgia would be the legal successor of the democratic republic of Georgia of 1918-1921 years. However, after dismantlement of the Soviet Union diverse countries in the world and UN recognized independence of Georgia not as of successor of the democratic republic of Georgia, but as a successor of the soviet socialistic republic of Georgia.
} 
had a negative influence on the public administration sphere. The legal nihilism was so strong that that prevented firstly creation of such administrative legislation, which would be based on human rights. Given that the communist doctrine linked public administration not to the rules of law principle, but the will of communist party, the administrative legislation reflected only the will of the prevailing class, which was given to administrative bodies in form of directives by the communist party. Administrative law was equated only with the Administrative Offences Code that stipulated administrative offences and types of responsibilities/sanctions.

In the democratic and legal state public administration and administrative legislation regulating it have functions of ensuring basic human rights, order, protection, provision of service and democratic guarantees. In everyday life, realization of these functions (public and private) is done by the administrative legislation. Considering the European legal experience in this sphere, for which human is considered as a main value, has only a positive impact on the increase of standard of protection, control and stability. Clearly, in the conditions of state constitutional identity, this only facilitates the realization of those thoughts of legislator that are considered in general constitutional norms (Kalichava, 2017: 289). Therefore, preparation of both draft codes in Georgia was carried out according to experiences of administrative legal orders from different western countries. Experts from Netherlands, Germany, France and US participated in the preparation of draft laws, in order to share experiences of their countries. At the end, the group of reformers agreed on the reception of Dutch and German models of administrative law.

\subsection{Need for creation of new administrative law}

After the political changes, namely collapse of the Soviet Union, the political will of Georgia appeared to aim at establishing bodies based on totally new concept and transform into democratic and lawful country. Consequently, the development of administrative law was put on the agenda in a way that it would regulate public administration and legal affairs between citizens, the role of public administration in the protection of citizens' interests and rights should have been increased. Therefore, during the codification of administrative law it is advisable to define general principles of administration. Inasmuch as, the purpose of regulating principles under legislation is that citizen, who reads the law, may understand the main essence of the law promptly (Winter, 2013: 68).

The idea of codification of administrative law initiates from 1997, after Georgia has become a member of the Council of Europe and took an obligation to put the legislation into the framework of the rule of law principles. On September 2 of 1997 the Parliament of Georgia adopted resolution on "the harmonization of the Georgian legislation with the European Union law" (Parliament of Georgia, 1997), according to which from September $1^{\text {st }}$ of 1998, all laws and other normative acts shall be adopted in compliance with the standards and norms prescribed by the European Union. The purpose of mentioned normative obligations was to develop processed of integration of Georgia into international institutions of Europe, approximate and harmonize legal systems, to ensure compliance of Georgia legislation with principles recognized by the European Union.

The new administrative law stood before the necessity to solve problems of various and, at the same time, complex nature. Consequently, the role of the legislative body of those times was highly important, as it stood before a big challenge. In particular, 
the issue of privatization of state assets, legislative guarantees of the freedom of entrepreneur, decentralization of administration and many other issues, which are important for establishment of the state of market economy, required legislative amendments.

As stated by the German scholar Gerd Winter, among the transitional countries the transformation of Georgian legal order is exemplary for two grounds: first is that Georgia promptly conducted changes in the legal form and comparing to other Eastern or Asian, or CIS countries managed to develop rapidly (Winter, 2013: 68). The Parliament of Georgia on June 25 of 1999 (Parliament of Georgia, 1999a) adopted the General Administrative Code of Georgia, and on July 23 of the same year - the Administrative Procedure Code (Parliament of Georgia, 1999b). Exactly by the adoption of these two codes, the development of new administrative law, as of discipline of law, has started in Georgia.

\section{Review of the reform implemented in the administrative law}

\subsection{I stage of the reform of administrative law}

As mentioned above, in 1999, since Georgia became member of the Council of Europe, protection of human rights turned out to be the priority issue within the national legislation. Therefore, the formation of modern administrative law in Georgia was leaded in two directions: one in the legislative regulation of public administration and second in creation of administrative justice (Adeishvili et al., 2005: 22). Georgian legislator decided to regulate the relations aroused between citizen and state in the substantial as well as in procedural framework by adopting separate acts. Often, in countries of continental law system, substantial and procedural administrative norms are regulated separately. Distinctive regulation of the legislation is related to those important legal affairs that, on one hand, are regulated by the substantial administrative legislation and, on the other, hand by the procedural administrative legislation. Substantial administrative law regulates the entitlement of administrative body to interfere in the rights, hence prescribes thematic-essential provisions between the person and administrative body. The administrative justice defined the rules according to which the process of decision making takes place in court. Hence, there is a interdependent close connection between those, as well as there is a significant distinction. Therefore, for compiling substantial and procedural norms in one legislative act it is important to have string argument, which would justify not only the effectiveness of its usage from technical perspective, but first would clarify the legitimate purpose of regulating administrative law relations.

In Georgia, the administrative law consists of general and special parts. The general part entails general norms regulating governmental sphere. General administrative law stipulates core rules for activities of governing bodies and covers any governing institution, despite the activity of this institution, and the special part of the administrative law entails particular components of public law; additionally, it regulates certain areas of governmental activities, according to the group of objectives (e. g. police law, construction law, social law, etc.).

\subsection{II stage of the reform of administrative law}

The second crucial stage of the development of administrative law started in 2014. Namely, on June 27 of 2014 the Association Agreement (AA) ${ }^{3}$ was signed between Georgia and the European Union, according to which one of the proclaimed core obligation is that

\footnotetext{
${ }^{3}$ Association Agreement between the European Union and the European Atomic Energy Community and their Member States, of the one part, and Georgia, of the other part, 27/06/2014. URL: https://matsne.gov.ge/document/view/2496959? publication=0.
} 
parties shall further strengthen respect for fundamental freedoms, human rights, including the rights of persons belonging to minorities, democratic principles, the rule of law, and good governance, based on common values of the Parties. Therefore, in the framework of the EU-Georgia Association Agreement Georgia committed itself to strengthen good governance. Following this, in 2016 the constitutional reform took place in Georgia, based on which numerous amendments were introduced into the Constitution of Georgia. One of the amendments concerns obligation of administrative bodies to ensure good governance. Particularly, as a result of reform the new record was introduced in the Constitution, which ensures engagement of a person in the process of public administration. The new edition of the Constitution of Georgia offers a new right in the catalogue of fundamental rights in the form of good governance, namely, according to article $18^{4}$ of the constitutional law of Georgia "on the amendments to the Constitution of Georgia", person has a right to have the case related thereto, deliberated fairly by the administrative body within a reasonable period of time. Current provision ensures the right of a person to address administrative body for fulfillment of his/her interests and queries, as well as to participate in the administrative proceeding, get aware of case materials, also an obligation of administrative body to justify its decision and deliberate the case in reasonable period.

According to the new edition of the Constitution of Georgia, good governance, as well as codification of fundamental right in the main law of the country, will facilitate the protection of person's rights and effectiveness of public administration. Therefore, such provision represents a "new category" of fundamental right, by which the basic principles of administrative proceeding are constitutionalized, and this represents a novelty for the Georgian legal sphere. Moreover, the mentioned provision will facilitate development of good governance, as a fundamental right (Tskhadadze, 2017: 54).

\section{Scope of the General Administrative Code of Georgia}

\subsection{Notion of administrative body}

Even though, the notion of administrative body in the administrative law gives possibility for non-uniform interpretation, that is why regulation of its legal definition in the code evidently often does not solve the problem, however for definition of adminis-

\footnotetext{
${ }^{4}$ Article 18 "Rights to fair administrative proceedings, access to public information, informational self-determination, and compensation for damage inflicted by public authority":

1. Everyone has the right to a fair hearing of his/her case by an administrative body within a reasonable time.

2. Everyone has the right to be familiarized with information about him/her, or other information, or an official document that exists in public institutions in accordance with the procedures established by law, unless this information or document contains commercial or professional secrets, or is acknowledged as a state secret by law or in accordance with the procedures established by law as necessary in a democratic society to ensure national security or public safety or to protect the interests of legal proceedings.

3. The information contained in official records pertaining to an individual's health, finances or other personal matters shall not be made available to anyone without the consent of the individual, except as provided for by law and as is necessary to ensure national security or public safety, or to protect public interests and health or the rights of others.

4. Everyone shall be entitled to full compensation, through a court, for damage unlawfully inflicted by the bodies of the State, the autonomous republics and local self-governments, or their employees, from state funds, the funds of the autonomous republics or the funds of local self-governments, respectively.
} 
trative proceeding and specification of the scope of the judicial code, it is important to define the meaning of administrative body.

The General Administrative Code defines the notion of administrative body, according to which administrative bodies are the State, the self-government institutions, also any other entity, which are equipped with public law powers for ensuring public and private interests.

In light with the definition, first part if the organizational conception of administrative body (state and local self-government institutions), and second part represents the functional conception ("any other entity"). In this case, the second part of the definition is important as we mention here not state bodies, but any other entity, which is not a state institution and does not represent the subject of relations of public law however, based on the legislation carries out public powers. Under "any other entity", we assume legal entities of private law, which, in accordance with the legislation, may be equipped with public law powers by the State.

It shall be noted, that in practice public governance functions are transferred to private entities when it is necessary to have specialized knowledge and creation of public institution for that purpose would be linked to excessive costs. Whereas, private entities may exercise the power more effectively and with less costs. Consequently, it is not possible for legislative act to prescribe exhaustive list of those organizations, which may fall under the definition of administrative body and exercise public powers. For this reason, the guiding factor is the second part of the definition, its functional conception, according to which we may identify the subject, whether it executes the public authority or not.

\subsection{Forms of activity of administrative body}

In accordance with the General Administrative Code, administrative act (individual or normative act) stipulates the forms of activities of an administrative body, also the factual deed of an administrative body - real act, which has no legal outcome. However, it shall be noted that for being more flexible and effective public administration issues not only acts or implements particular actions, but also it may conclude an agreement as a form of mutual expression of will. Conclusion of an agreement by administrative body represents one of the most spread form of activity. Base on the type of the regulated relationship, administrative body may conclude agreements under private law, as well as public law. The important criteria for differentiating legal nature of an agreement is the purpose for which the agreement is stipulated, would it be under public law (administrative agreement) or aiming at creating private law relations. Hence, administrative agreement differs from other agreements by the object. Particularly, by virtue of an agreement administrative body delegates the power of exercising public functions to other party of the agreement.

\subsection{Principles of administrative law}

Not only general constitutional principles are outlined in the administrative legislations, such as: democratic state, state of law and principles of social state, but also it is regulated to have principles characteristic for administrative law, so-called special principles: effectiveness of public administration, discretional power of administrative bodies, right to lawful fidelity, publicity, impartiality. Special principles characteristic to administrative law are regulated in the General Administrative Code of Georgia, as well as in the Administrate Procedure Code of Georgia (Tskhadadze, 2016: 6). 


\subsubsection{Principle of legal reservation}

Requirements of State of law prescribe that the administrative act issued in accordance with the legislation by the administrative body with its content, purpose and scope shall be specified in a manner that the citizen has a possibility to foresee and "calculate" in advance the measures to be implemented under this act ${ }^{5}$. All these are directed to make interference of public governance more predictable. Legislator shall regulate the content of the activities of an administrative body and it should not be limited by general principles (Tskhadadze, 2016: 9).

\subsubsection{Discretional authority}

We come across the definition of discretional authority principle among definitions of terms in the General Administrative Code of Georgia, where the discretional authority is defined as liberty of an administrative body or administrative official to choose most acceptable decision among several decisions set by the legislation based on protection of public and private interests.

Granting discretional power does not mean full freedom of the administrative body, but the mentioned article sets framework of decision-making competence for respective administrative body. On one hand, it is limited by the requirement established by law, and on the other hand, considering the proportionality of public and private interests, which means that in every particular situation such interests shall be scaled and compared.

\section{Administrative justice in Georgia}

\subsection{Scope of the Administrative Procedure Code}

As it was stated above, in the Soviet Union times administrative justice existed only with regard to administrative offences. Inasmuch as administrative legal relations create guarantees for protection of rights and necessity for protection, therefore the existence of administrative justice is essential. By the adoption of Administrative Procedure Code in Georgia in 1999, the administrative legal disputes are deliberated by the administrative court. Firstly, the code regulated the institutional subordination of the court and also the issue of jurisdiction. Regulation of mentioned issues is very crucial as after positive decision on institutional subordination the question arises exactly which court shall deliberate and decide the case. In comparison to subordination, by virtue of which the powers are defined between diverse legal bodies, jurisdiction also defines the power, but only among courts (Kopaleisvhili et al., 2008: 141).

According to article 2 of the Administrative Procedure Code, the subject of the administrative dispute may be: a) compliance of the administrative legal act with the Georgian legislation; b) conclusion, implementation or termination of the administrative agreement; c) obligation of administrative body to restitute the damage, issue administrative legal act or implement other action; d) declaring nullity of an act, defining the existence or non-existence of the right or legal relations.

Along with the abovementioned, the Administrative Procedure Code outlines special types of administrative judicial procedure. Namely, the court deliberates by administra-

\footnotetext{
${ }^{5}$ Decision of the Federal Administrative Court of Germany from July 4 of 1956, (BVerwGE 4,24). URL: www.juris.de.
} 
tive legal process the case of placing person in hospital for the purpose of non-voluntary psychiatric assistance, also administrative judicial process on preclusion of domestic violence, protection and help for victims of violence, moreover administrative judicial procedure is used with regard to the realization of frozen assets of tax payer by the taxation body, and other cases.

Paragraph 3 of article 2 of the Administrative Procedure Code is crucial provision, according to which, besides the cases listed above, other cases are also deliberated in court with administrative legal procedure mostly related to those legal relations that derive from administrative legislation. Such provision enhances the scope of jurisdiction of administrative court and disputes are not deliberated with narrow sense only for checking the lawfulness of acts and real acts. At the same time, such provision gives possibility to differentiate civil, constitutional and administrative disputes.

\subsection{Review of amendments made to the Administrative Procedure Code}

The first edition of the Administrative Procedure Code that entered into force in 2000 entailed 35 articles. Afterwards this law has been amended 50 times approximately and nowadays comprises 48 articles and additional 30 articles on special proceedings. The main part of amendments represents the outcome of the practical experience and is related to very particular issues, especially adjusting terms for proceeding, involving third parties in the administrative process, administrative process on checking lawfulness of classification of secret information, types of claims, admissibility of types of complaints and prerequisites for justification, and admissibility of appellate and cassation complaints.

Certain factual circumstances resulted in introduction of special types of proceedings on administrative cases, which is a competence of administrative body by its nature, but considering their importance, competence of hearing such cases was given to judges deliberating administrative disputes, as for instance permitting the control of activities of an entrepreneur, preclusion of domestic violence, or placing person in the hospital with the purpose of providing psychiatric assistance.

The legislative strategy of the Administrative Procedure Code is that administrative cases most of the time are deliberated by using Civil Code. Therefore, the Administrative Procedure Code entails only those rules that are different from regulations of the Civil Code of Georgia. Despite this theoretically understandable line, there are doubts with regard to some paragraphs in court practice, namely: whether the regulations of the Civil Code are substituted by the regulations of the Administrative Procedure Code? Whether respective provisions of the Civil Code shall be used directly or with analogy?

For example: the legal condition of participants to the administrative process is regulated with respective norms of administrative, as well as civil procedure legislation. As it is known, legal relationship does not exist without parties and in this regard, the administrative law is not an exception. However, the Civil Procedure Code of Georgia defines the circle of subjects of administrative process. Article 14 of the Administrative Procedure Code, which concerns participants of the administrative procedure, stipulates that except persons defined in article 79 of the Civil Procedure Code of Georgia, the administrative body, which issued and administrative act or implemented action of legal relevance, participates in the administrative process. Therefore, administrative legislation broadens the circle of subjects in the process and introduces administrative body as a compulsory 
participant. This is the core distinctive feature of the administrative process comparing to the civil procedure law. In the administrative process beside the subjects mentioned above, administrative body must be party to the case either as a plaintiff, or as defendant. Moreover, according to the administrative legislation everyone has a right to participate by the representative in administrative legal relations.

Despite the similarity of legal institutes, the reference by the administrative law to use civil law provisions in the administrative process shall nor serve to the fact, that civil law provisions must be used directly by public law. Direct application of civil law forms destroys core distinctions between the public and private law, as administrative legal relations principally differ from private law relations by its essence. In particular, the expression of will by a person which is characteristic to private law, may confront the will of a State in public law. Herein it should be noted that using private law provisions does not always cover administrative legal relations, as far as regulation of administrative legal relations is impossible without administrative legislation (Tskhadadze, 2018: 36).

\subsection{Particularities of the administrative justice}

\subsubsection{Principles of administrative process}

By introduction of administrative legal procedure in Georgia, the significant principles of administrative process were also defined: principle of disposition, principle of inquisition, principle of leading process by the judge, principle of oral nature of judicial proceedings and principle of directness, principle of publicity, principle of adversary proceeding, principle of equality before the law, principle of independence and impartiality of the judiciary.

\subsubsection{Filing a complaint in the administrative body by administrative proceeding,}

\section{so called "prejudicial" rule}

According to paragraph 5 of article 2 of the Administrative Procedure Code, judge may not admit the claim against administrative body, except the occasions prescribed by law, if plaintiff did not use the single possibility to file administrative complaint as prescribed under the General Administrative Code of Georgia, which implies the prejudicial authority.

Prejudicialness entails restriction of person's right to apply the court until he/she will not exhaust the right of protection base on administrative regulation by filing complaint in the administrative body. Administrative rule of filing complain firstly implies protection of the right of a person in short period of time and it represents measure of self-control for the system of administrative body. Thus, contesting the decision in the administrative body as prescribed under law gives possibility to the interested party to claim review of a final decision made through the administrative proceeding.

Here we shall note that by itself, the right to apply the court does not fall into category of absolute rights. It may be restricted and, in such way, states are taking advantage of certain freedom to act. However, prescribed restrictions shall not limit the right to apply to the court tin a way that it loses its sense.

\subsubsection{Suspensive effect of the administrative compliant}

For ensuring the determination of real guarantees for the protection of person's rights and restoration of the infringed right effectively and promptly, important provision in the regulation of law, which concerns the suspension of the disputed act, in case the complaint is filed, until the final decision. According to this, administrative act is suspended until the decision is made. 


\subsubsection{Principle of disposition}

The basis for the principle of disposition lies in article 3 of the Administrative Procedure Code of Georgia. The principle of disposition gives possibility to parties of the process to decide individually issues such as application to the court, defining subject of the dispute and concluding case by settlement.

The principle of disposition gives leading role to parties of the process. Only plaintiff may determine in what scale he/she will apply to the court. The principle of disposition gives parties a possibility to decide by themselves whether to settle or not. In light of the principle of dispositions parties also decide the issue of presenting evidence and when necessary revoking evidence. The result of the principle of disposition is that by its virtue it is possible to admit the claim or settle in certain cases (Kopaleisvhili et al., 2008: 21).

\subsubsection{Principle of inquisition}

The content of the principle of inquisitions is that the court hearing administrative case is entitled, deriving from public interest, to make efforts on his/her own initiative for obtaining the evidence necessary to deliberate the case. The judge on his/her own initiative or by motion of the party may obtain evidence necessary for discussion of the administrative dispute.

The ground for the principle of inquisition lies in article 4 of the Administrative Procedure Code of Georgia, according to which " $<\ldots>$ Court is entitled on its own initiative to make decision on receiving additional information or presenting evidence".

The principle of inquisition applies in occasions, when in relation to the particular case there is a specific public interest. This is the occasion when the existence of public interest influences the decision. In case of existence of public interest, the decision on the administrative case and prerogative to find objectively the evidence and circumstances in order to identify the truth, may not be entrusted only to the parties. In such case, the title of the court to define the issue of presenting evidence required for the case and investigate on its own respective circumstances, is the prerequisite for protection of public interest (Kopaleisvhili et al., 2008: 21).

\subsection{Institute of Amicus Curiae}

Institute of "amicus curiae" is very important one in terms of increasing involvement of interested parties and executing justice effectively. The institute of amicus curiae means that any person who is not party to the dispute or a third party, may present his/ her written opinion regarding this case. The purpose of presenting written opinion must be supporting any of the parties to the case. This written opinion must help court in properly evaluating the discussed issue. If the court considers that the written opinion is not drafted in compliance with the requirements stipulated in this provision, the opinion will not be deliberated. The court is not obliged to share the arguments presented in the written opinion, however, if he/she considers it necessary, may use the opinion sent by amicus curiae. This opinion may be reflected in the motivational part of the decision.

\section{Conclusions}

Deriving from all presented above, development of new ideas and concepts in Georgia resulted in the necessity of reforming administrative law. Georgian administrative law experiences reform of several stages. The first stage of the reform is 
linked to the period of declaration of independence of Georgia and to an important fact, when Georgia became member of the Council of Europe and took an obligation to harmonize legislation with the European Union legislation, what entailed putting all laws and bylaws in compliance with the standards and norms defined by the European Union. The first results of the reform implemented in Georgia are the General Administrative Code and the Administrative Procedure Code of Georgia adopted in 1999. Adoption of these codes became foundation for developing new type of administrative law, as the discipline of administrative law was developing in completely different direction in the period when Georgia under the soviet regime, administrative procedure law and separate discipline and legislation did not exist at all. Herein, we shall note that experiences of administrative legal order of diverse western countries played crucial role in the creation of substantial and procedural administrative legislation in Georgia. Namely, reception of German, Dutch and American legal systems was made into Georgian legislation. As far as administrative law is linked to everyday life, factual and legal variety of modern environment influences greatly the codification of discipline, the issue of constant change of the legislation arises, but despite that, Georgian administrative law does not stray from the purpose which was set in 1999 by creation of new administrative law.

Inasmuch as according to the Association Agreement, ensuring protection of human rights, rule of law and good governance is one of the priorities of public administration. Therefore, after signing the Association Agreement next phase of reforming Georgian legislation is initiated. Herein, we shall note that amendments of Georgian administrative law shall respond to the criteria of State of Law, also while adopting provisions the socio-economic reality existing in Georgia shall be taken into consideration.

As it was mentioned above, transition from the soviet system to post-soviet system touched almost all areas of life. State institutions developed, democratization was undergoing, etc., what is not achievable with the highest quality from the very start. In such occasions states, which have to transit to the completely different legal system, directly transpose models of democratic, developed countries, which mostly is done mechanically and without thinking through. Hence, the Georgian administrative law, where "translation" was done directly from German-Dutch legal system, also is undergoing a reform and specification of certain provisions or institutes.

The fact that a lot of changes are introduced in the Georgian administrative legislation is a result of many factors, at the same time, establishing innovatory ideas is not easy within the activity of administrative bodies. By virtue of these codes, certain provisions are being realized in practice gradually, which in itself has a negative impact on effective public governance. Therefore, studying and researching actual issues in the administrative law will facilitate effective and qualified work of public administration; simultaneously ensure making justified decisions by administrative bodies.

In light of the abovementioned, Georgia has moved forward by one more step on this path, towards normal everyday life of the society, which expects regulation action from the administration and wants to participate in this process, and in case of illegal actions it is ensured with the protection of rights. 


\section{Bibliography:}

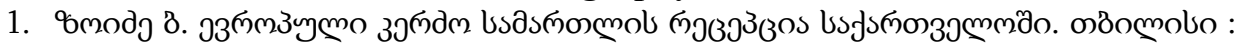

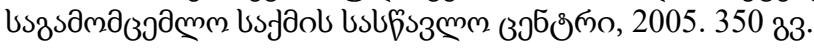

2. Коркунов Н.М. Лекции по общей теории права. Санкт-Петербург, 2004. 458 с.

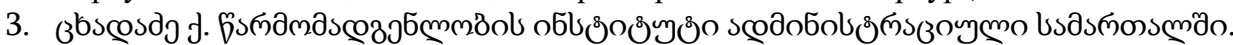

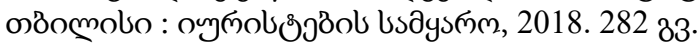

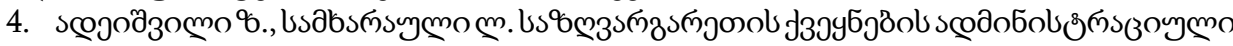

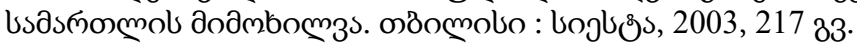

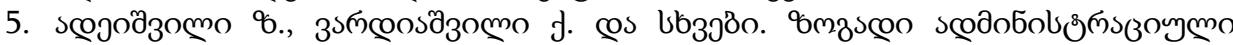

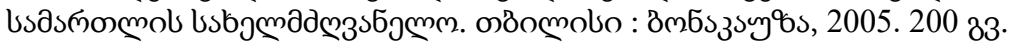

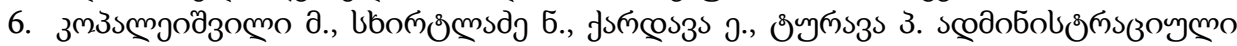

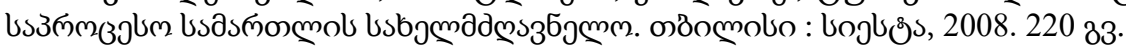

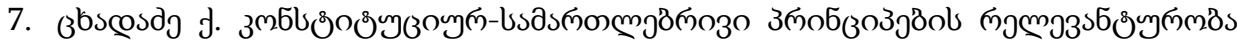

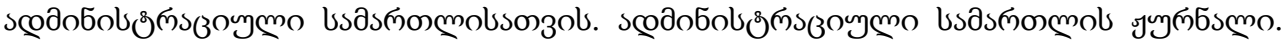
2016. № 2. 33. 5-15.

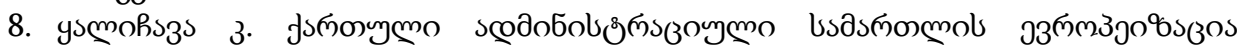

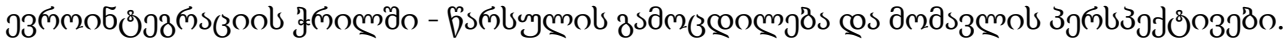

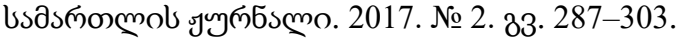

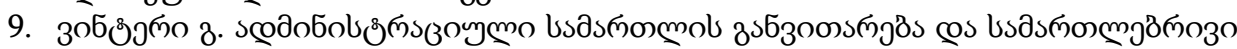

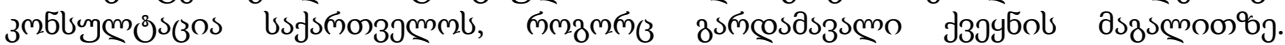

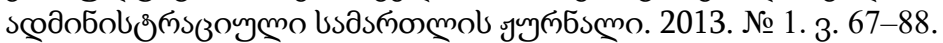

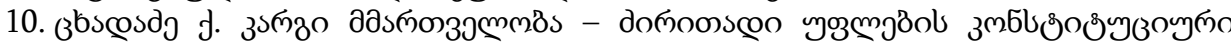

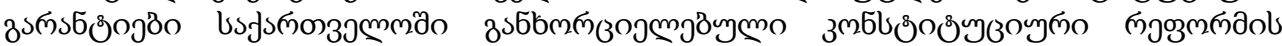

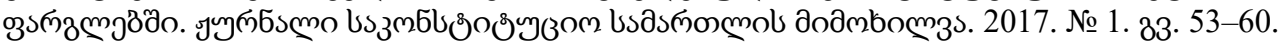

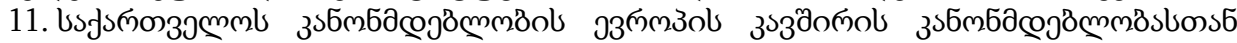

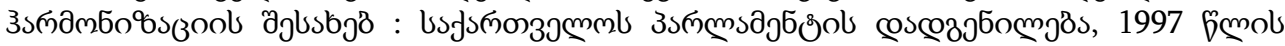

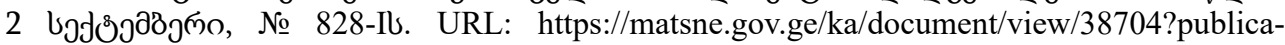
tion $=0$ (access data: 01.04.2019).

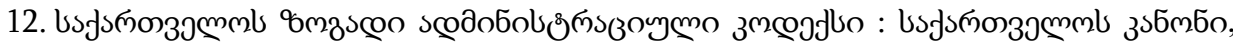
1999 6mol 25 o360lo, № 2181-IIb. URL: https://matsne.gov.ge/ka/document/view/16270?publication $=30$ (access data: 01.04.2019).

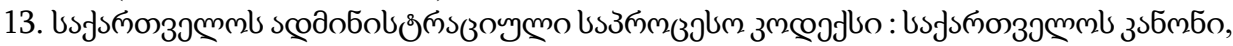
1999 6mol 23 o3mobo, № 2352-ґl. URL: https://matsne.gov.ge/ka/document/view/16492?publication $=73$ (access data: 01.04.2019).

\section{References:}

1. Zoidze, B. (2005). Evropuli Kerdzo Samartlis Recepcia Saqartveloshi [Reception of the European Private Law in Georgia]. Tbilisi: Sagamomtsemlo saqmis sastsavlo Centri [in Georgian].

2. Korkunov, H.M. (2004). Lekcii po obshei teorii prava [Lectures of the common theory of law]. Saint Petersburg [in Russian].

3. Tskhadadze, K. (2018). Tsarmomadgenlobis Instituti Administraciul Samartalshi [Institute of the Representative in administrative law]. Tbilisi: Iuristebis Samyaro [in Georgian].

4. Adeishvili, Z., Samkharauli, L. (2003). Sazgvargaretis qveynebis administraciuli samartlis mimokhilva [Review of the administrative law of foreign countries]. Tbilisi: Siesta [in Georgian].

5. Adeishvili, Z., Vardiashvili, K., Izoria, L., Kalandadze, N., Koplaeishvili, M., Skhirtladze, N., Turava, P. (2005). Zogadi administraciuli samartlis sakhelmdzgavnelo [General Administrative Law Handbook]. Tbilisi: Bona Kauza [in Georgian]. 
6. Kopaleisvhili, M., Skhirtladze, N., Qardava, E., Turava, P., (2008). Administraciuli saproceso samartlis sakhelmdzgvanelo [Administrative Procedure Law Handbook]. Tbilisi: Siesta [in Georgian].

7. Tskhadadze, K. (2016). Konstitutsiur-samartlebrivi principebis relevanturoba administraciul samartlisatvis [The relevance of the constitutional-legal principles for the administrative law]. Administrative Law Journal, no. 2, pp. 5-15 [in Georgian]

8. Kalichava, K. (2017). Qartuli administraciuli samartlis evropeizacia evrointegraciis chrilshi - Tsarsulis gamotsdileba da momavlis perspeqtiva [Europeanisation of the Georgian Administrative Law in the view of Euro integration - past experience and future perspectives]. Law Journal, no. 2, pp. 287-303 [in Georgian].

9. Winter, G. (2013). Administraciuli samartlis ganvitareba da samartlebrivi konsultacia saqartvelos rogorc gardamavali qveynis magalitze [Development of Administrative law and legal consultation on the example of Georgia, as the transitional Country]. Administrative Law Journal, no. 1, pp. 67-88 [in Georgian].

10. Tskhadadze, K. (2017). Kargi Martveloba - konstituciuri garantiebi saqartveloshi gankhortsielebuli konstitutsiuri reformis farglebshi [Good Governance - Constitutional guarantees of fundamental right in the scope of the constitutional reform implemented in Georgia]. Journal Review of Constitutional Law, no. 1, pp. 53-60 [in Georgian].

11. Parliament of Georgia (1997). Sakartvelos kanonmdeblobis Evropis kavshiris kanonmdeblobastan harmonizatsiis shesakheb: Sakartvelos Parlamentis Dadgenileba, 1997 tslis 2 sektemberi, № 828-Ib [On Harmonization Legislation of Georgia with the legislation of the European Union: Resolution of the Parliament of Georgia dated September 2, 1997, № 828-Ib]. Retrieved from: https://matsne.gov.ge/ka/document/view/38704?publication=0 [in Georgian].

12. Parliament of Georgia (1999a). Sakartvelos zogadi administratsiuli kodeksi: Sakartvelos Kanoni, 1999 tslis 25 ivnisi, № 2181-IIl [The General Administrative Code of Georgia dated June 25, 1999 № 2181-IIl]. Retrieved from: https://matsne.gov.ge/ka/document/view/16270?publication $=30$ [in Georgian].

13. Parliament of Georgia (1999b). Sakartvelos administratsiuli saprotseso kodeksi: Sakartvelos Kanoni, 1999 tslis 23 ivlisi, № 2352-øu [The Administrative Procedure Code of Georgia dated July 23, 1999 № 2352-(๓)]. Retrieved from: https://matsne.gov.ge/ka/document/view/16492?publication $=73$ [in Georgian].

\title{
РОЗВИТОК АДМІНІСТРАТИВНОГО ПРАВА В ГРУЗІЇ
}

\author{
Кетеван Цхададзе, \\ декан юридичного факультету \\ Відкритого Тбіліського університету, \\ доктор юридичних наук, професор \\ orcid.org/0000-0003-0585-6943 \\ k.tskhadadze@openuni.edu.ge
}

Мета. 3 прийняттям у Грузії в 1999 роиі Спільного адміністративного кодексу та Адміністративно-проиесуального кодексу була закладена основа створення нового адміністративного права, оскільки до набрання чинності ицими кодексами Грузія не мала традииї адміністративного права та, відповідно, практики адміністративного правосуддя. У Грузії, яка входила до складу Радянського Союзу, як і в Радянському Союзі загалом, адміністративного права в тому розумінні, яке регулюється сучасним адміністративним правом, не було. Комуністична доктрина адміністративного права 


\section{ЗАРУБІЖНЕ АДМІНІСТРАТИВНЕ ПРАВО ТА ПРОЦЕС}

радикально відрізнялася від сучасного адміністративного права, оскільки адміністративне законодавство того часу було правом, яке переважно встановлює зобов'язання громадян щзодо адміністрації, а не засобом, що забезпечує захист прав громадян і їхніх інтересів.

Методи. У статті аналізуються етапи створення та подальшого розвитку грузинського адміністративного правосуддя, загострюється увага на основних принципах, які передбачаються грузинським адміністративно-прочесуальним правом. У иьому сенсі значне місие відводиться особливостям адміністративного провадження й судочинства в Грузії, зокрема так званому «преюдииіальному» порядку оскарження в адміністративному органі в адміністративному порядку, суспензійному ефекту адміністративної скарги, принциипам диспозитивності та інквізиційності в адміністративному процесі. Також розглядається інститут одного суду як особливість адміністративного правосуддя.

Результати. Значне місие в статті приділяється розгляду предмета адміністративного права та системи адміністративного права на прикладі грузинського адміністративного права. Розглядаються основні елементи здійснення публічного управління, поняття адміністративного органу, форми діяльності адміністративного органу та ті основні принципи, які характерні для грузинського адміністративного права.

Висновки. У наведеному плані важливе місие відводиться особливостям адміністративного судочинствай судового проиесув Грузї̈, асаметакзваній «досудовій» нормі оскарження в адміністративному органі, щзо припиняє дію адміністративного оскарження, принципам диспозитивності й дізнання в адміністративному процесі, а також інституту «атісиs сигіае» («друг суду»). Обговорюються особливості грузинського адміністративної юстиції.

Ключові слова: грузинське адміністративне право, рецепція правової системи, Загальний адміністративний кодекс Грузії, Адміністративно-процесуальний кодекс Грузії. 